\title{
A Research Analysis of the Non-use Value of the Industrial Heritage of the Middle East Railway
}

\author{
Jun ZHANG \\ Civil Engineering Institute \\ Northeast Forestry University \\ Harbin, China
}

\begin{abstract}
Use-value and non-use vale are the vital composition of the economical value of the industrial heritage. This paper acquired respectively the investigation data of Ang'ang $\mathrm{Xi}$ district, Yimianpo town and Hengdaohezi town by applying the Contingent Valuation Method (CVM) and combining the design and distribution of unilateral two fractional questionnaires. Through the analysis and calibration, the paper came to the conclusion regarding the non-use value of the above three locations and the comparison research. The factors influencing the non-use value are analyzed, which provides reference for the further non-value research of the industrial heritage of the Middle East Railway.
\end{abstract}

Keywords-non-use value; contingent valuation method; WTP

\section{CLASSIFICATION OFTHE INDUST RIAL HERITAGE VALUE}

Both Use-value and Non-use value contain different value types, forming jointly the gross value of the environmental value. Both have important position in the value system of industrial heritages. Their most significant difference lies in whether the service and products provided by the environmental resources have been utilized. (See Table 1)

TABLE I. VALUE ClASSIFICATION OF THE INDUSTRIAL HERITAGE

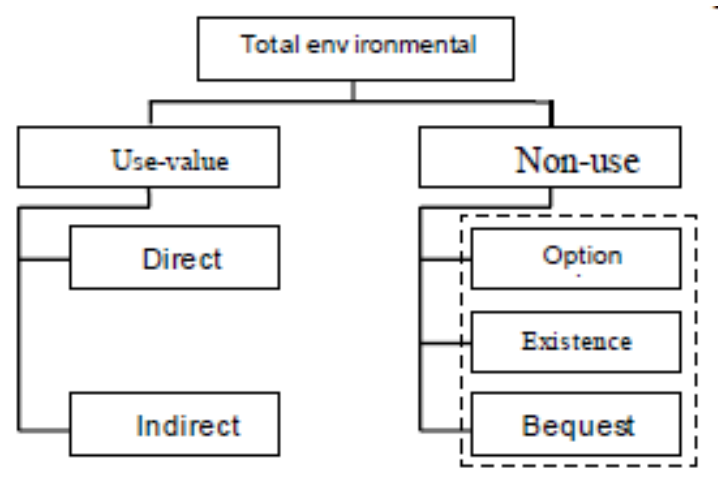

A. Use-value

The use-value of industrial heritage comprises direct use-value and indirect-use value. It mainly consists of minerals and energy (direct-use value) provided by the environment resources and the climate control and soil and

\author{
Shanshan LIU \\ Department of mechanical and electrical engineering \\ Tongliao Vocational College \\ Tongliao, China \\ e-mail: 18645947199@163.com
}

water conservation (indirect-use value) similar to that in ecology.

\section{B. Non-use Value}

The non-use value is a non-marketing value with noncompetiveness to be used by oneself or his descendents. Having never been utilized before, its economical value cannot be measured, thus often neglected. The non-use value comprises mainly the following three kinds of values:

- Option Value (OV): The option value means the price that an individual or organization is willing to pay in order to use the environmental resource selectively. It can also be understood as the price that people are willing to pay to have the industrial heritage to be preserved in the future.

- Existence value (EV): The existence value refers to the paying willingness expressed by the people to preserve some certain environmental resource without exploiting any interests. With the increase of the environmental protection consciousness, the existence value's proportion in the gross economical value would gradually increase.

- Bequest value (BV): Bequest value refers to the price that the contemporary generation is willing to pay to preserve some specific environmental resource to be used by the dependents (having nothing to do with the generation itself).

\section{SUMMARY OF EVALUATION OF CONDITIONAL VALUE MET HODS (CVM)}

The research of non-market resource value started initially in 50's last century, originating in America. The Contingent Valuation Method (CVM) is suitable for the nonmarket conditions, where the actuality of willingness that people pay for the environment resources is assessed to dig out the potential value of the environ mental resources from a deeper level by analyzing the feedback and data collected from the interviewed. In the past 50 years, CVM has been widely applied in western countries. With the researched cases being progressively increased, its credibility and reliability have gained more acknowledgements in China [3]. In 80's of 20th century, large number of scholars studying CVM theory emerged in China. And ten years later, case study and exploration research using CVM came onto the stage. Our scholar Xue Dayuan and his colleagues conducted a detailed research on the non-use value of the Natural 
Conservation Region of Changbai Mountain, initiating the application of CVM to the heritage resources evaluation and leaving profound influence on the further research. Some shortcomings still exist with regard to the CVM research in China due to the short time since the introduction of CVM into China. Further research should be made in many aspects such as the option of the key technology and guiding methods, the determination of the audience objects and radiation scope, designing of the questionnaire, selection of the investigated data and the verification of the conclusion's validity etc. Apart from this, as China is still developing country, it is still a question whether the CVM evaluation system can be directly applied to our heritage resources? How to eliminate the deviation existing with the CVM itself? To answer these questions, this paper makes an analys is and improvements by attempting to make a on-site investigation using the heritages of the Middle East Railway as an example and combing with the basic condition of our country.

\section{A BRIEF INT RODUCTIONTO THE HT REE TYPICAL AREAS ANDTHE INVESTIGATION COURSE}

\section{A. Brief Introduction to the Investigated Areas}

Ang'angxi district, Yimianpo town and Hengdaohezi town, having great number of industrial herigates, are located in Heilongjiang province, all known as the important towns along the Middle East Railway. Many of the historical sites, transport infrastructures, production process and etc have been included to the key protection objects of the state. As the industrial heritages of the Middle East Railway and with a long history which can trace back to the remote past, some of them are still in use and possess great reuse value as the industrial landscape.

\section{B. Composition of the Investigation Questionnaire}

The design of the investigation questionnaire: preliminary investigation, trial investigation and actual investigation. The problems existed in the preliminary and trial investigations were optimized and an actual investigation questionnaire was thus formed.

The questionnaire's contents distributed: the first part contains a brief introduction to the profile of industrial heritages of the Middle East Railway with the purpose of having the questioned familiarize to some extent the objective and content of the investigation; the second part is to collect the behavioral information of the local questioned people including their visiting experiences, understating degree and the cognition of the industrial heritage; and the third part includes the introduction to the concept of the nonuse value and the pay willingness regarding different use values expressed by the questioned; the forth part contains the human body characteristics and the basic information (including the inhabitation, inhabitation duration, sex, ages, monthly income, education level and occupations) of the questioned.

Form of the questionnaires distribution: the questionnaires were distributed at random to the local residents in the three above mentioned areas and their adjacent cities and towns and villages by the topic research members, who are divided into three teams and each them has 3 people. The questioned were asked to give their rep lies on site and each questionnaire was completed with the assistance of the research member. The reas on we choose to conduct the research locally lies in: one aspect is to enable the distributed questionnaires to gain bigger samples in relatively shorter time and another aspect is to satisfy the precision requirement. Based on the condition of the excessively young people and those who have no paying ability, this research focuses on the people group whose ages range between 18and 60 .

The questionnaires were distributed in Ang'angxi district, Yimianpo town and Hengdaohezi town and their

The locations where the questionnaires were distributed includes: Ang'angxi district: railway station, Bexing road (the original Rossiya street), the martyr cemetery, the square in front of the railway station; Yimianpo town: Yimianpo railway station, the farmer's market, the railway school, the central hospital, the police station; and Hengdaohezi town: the railway station, the township government, the railway security administration center, the village hospital and the school etc.

The format of the questionnaires: in now days, Ce format questionnaire is most widely used in the field of economical value of environmental goods. Therefore, this research on the use value of the industrial heritage adapts this kind of format, avoiding the negative inducement of the domestic payment card' one and enhancing the validity of CVM.

The bid value of the investigation questionnaires: Ang'angxi district and Yimianpo town (figure unit: RMB Yuan): 5; 10; 20; 25; 30; 35; 40; 45; 50; 55; 60; 70; 80; 90; $100 ; 110 ; 120$ and Hengdaohezi town (figure unit: RMB Yuan $): 2 ; 5 ; 15 ; 20 ; 25 ; 30 ; 35 ; 40 ; 45 ; 50 ; 55 ; 60 ; 65 ; 70 ; 75$; $80 ; 85 ; 90 ; 95 ; 100$.

\section{DAT A ANALYSIS AND NON-USE VALUE EST IMATE}

\section{A. Questionnaires Feedback and Sample Information}

The information and data used in this research of non-use value of industrial heritages were derived from the situ investigation made in May, 2013. Respectively 300, 280 and 250 questionnaires were distributed in A (Ang'angxi district), $\mathrm{B}$ (Yimianpo town) and C (Hengdaohezi town), of which 270, 245 and 238 were collected back. Through preliminary statistics, the total numbers of the effective questionnaires were respectively 250, 237 and 230. Damages in the distribution and incomplete information provided by the questioned are the main reasons for the occurrence of the invalid questionnaires. Moreover, the research met no protests or any bad phenomenon like obvious refusal to be questioned.

According to the above statistics, it can be seen that the distribution of the questionnaires regarding the industrial heritages of the Middle Railway is a success, which provides preferential grounds for the series of future analysis and research. We can see from Table 4 that the nearer the distance from the questioned area to the industrial heritages, the higher the rate of percentage of the paying willingness, 
which presents a normal distribution with the psychological attributes of the inhabitants and vice versa. (See Table 4 for the details )

After being screened and cut the collected questionnaires of the three typical areas were tested regarding their cross charts, freedom degree and chi-square values by applying the statistics software SPSS17.0. The relativity between the various economical and social characteristics of the sample group for the domicile $\mathrm{A}, \mathrm{B}$ and $\mathrm{C}$ and their corresponding paying willingness was vindicated (A: Ang'angxi District, B: Yimianpo town and C: Hengdaohezi town). The statistics of Table 7 shows unanimously an insignificant relativity between sex and paying willingness. This indicates that the sexhas no explanation ability toward the paying willingness, while, the domicile, age, education level, occupation, monthly income and past visiting experience and the familiarity has explanation ability of different degrees toward the paying willingness. (See the details in Table 5).

TABLE II.DISTRIBUTION OF THE INDUSTRIAL HERITAGES IN THE INVESTIGATED AREAS

\begin{tabular}{|c|c|c|}
\hline Area in vestigated & Geological location and classification & $\begin{array}{c}\text { Typical andhistorical relics are not } \\
\text { permitted to destroy }\end{array}$ \\
\hline $\begin{array}{c}\text { Qiqihar } \\
\text { (Ang'angxi District) }\end{array}$ & $\begin{array}{l}\text { With a distance of } 18 \text { kilometers from } \\
\text { Qiqihar, an excellent geological location, } \\
\text { Ang'angxi railway station belongs to a } \\
\text { grade } 2 \text { station house, and was once one of } \\
\text { the important barracks along the Middle } \\
\text { East Railway. }\end{array}$ & $\begin{array}{l}\text { Ang'angxi railway station and the Rossiya } \\
\text { Street style( now called Beixing Street and } \\
\text { already included to the National Historical } \\
\text { Streets), the site of the Middle Railway } \\
\text { Club and the residential houses of the } \\
\text { railway workers. }\end{array}$ \\
\hline $\begin{array}{l}\text { Yimianpo Town in } \\
\text { Shangzhi city }\end{array}$ & $\begin{array}{l}20 \text { kilometers away from Shangzhi city, } \\
\text { Yimianpo railway station acted as the } \\
\text { returning station of Suibin line of that time. } \\
\text { The station, a grade } 3 \text { station house, has a } \\
\text { complete facilities and huge number of } \\
\text { construesthat have been fully protected. }\end{array}$ & $\begin{array}{l}\text { Yimianpo railway station house, barracks } \\
\text { site, site of trainmen apartment, powder } \\
\text { mill, Railway hospital, Russian style } \\
\text { wooden house, and etc. }\end{array}$ \\
\hline $\begin{array}{l}\text { Hengdaohezi town in } \\
\text { Hailin city }\end{array}$ & $\begin{array}{l}61 \text { kilometers from Hailin city, Hengdaohezi } \\
\text { town is situated on the throat of the Middle } \\
\text { East Railway and the joint station of Suibin } \\
\text { line. With a long history, more than } 200 \\
\text { architectures have been well protected. }\end{array}$ & $\begin{array}{l}\text { Big white house of Hengdaohezi railway } \\
\text { station, Old Russian style street, Yuejinske } \\
\text { Church, Railway police station, Far East } \\
\text { Frauenkirche Cathedral, engine house and } \\
\text { Russian style wooden house. }\end{array}$ \\
\hline
\end{tabular}

TABLE III.

DistRIBUTION OF THE QUESTIONERS IN THE THREE AREAS AND THE PA YMENTPERCENTAGE

\begin{tabular}{|c|c|c|c|c|}
\hline Region & $\begin{array}{c}\text { Numberof people } \\
\text { distributed }\end{array}$ & $\begin{array}{c}\text { Number of valid } \\
\text { people }\end{array}$ & Effecti veness/\% & $\begin{array}{c}\text { Percentage of the } \\
\text { total/\% }\end{array}$ \\
\hline Ang'ang Xi District & 180 & 157 & $87.22 \%$ & $62.80 \%$ \\
\hline Qiqiha'er & 40 & 32 & $80 \%$ & $12.80 \%$ \\
\hline Harbin & 35 & 27 & $77.14 \%$ & $10.80 \%$ \\
\hline $\begin{array}{c}\text { Other province or } \\
\text { cities }\end{array}$ & 45 & 34 & $75.56 \%$ & $13.60 \%$ \\
\hline Yimianpo Town & 165 & 149 & $90.30 \%$ & $62.87 \%$ \\
\hline Shangzhi & 50 & 39 & $78 \%$ & $16.46 \%$ \\
\hline Harbin & 30 & 21 & $70 \%$ & $8.86 \%$ \\
\hline $\begin{array}{c}\text { Other province or } \\
\text { cities }\end{array}$ & 35 & 28 & $80 \%$ & $11.81 \%$ \\
\hline Hengdaohezi & 182 & 171 & $93.96 \%$ & $74.35 \%$ \\
\hline Hailin & 32 & 29 & $90.63 \%$ & $12.24 \%$ \\
\hline Harbion & 18 & 15 & $83.33 \%$ & $6.33 \%$ \\
\hline $\begin{array}{c}\text { Other provinces or } \\
\text { cities }\end{array}$ & 18 & 15 & $83.33 \%$ & $6.33 \%$ \\
\hline
\end{tabular}

TABLE IV.

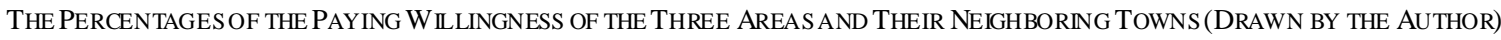

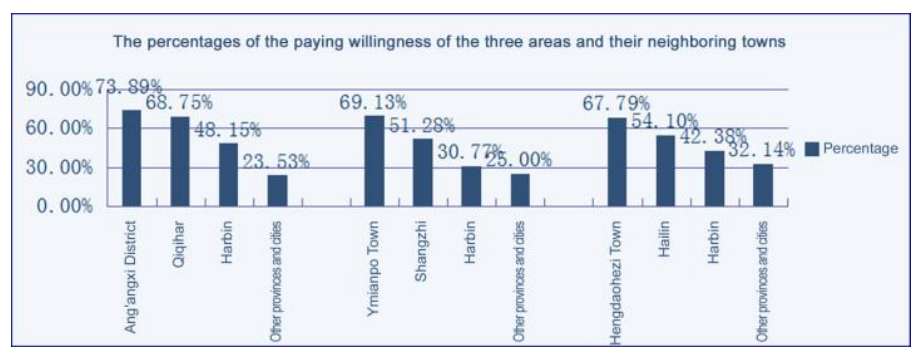


TABLE V.ANALYSIS OF THE INFLUENCE OF THE RELEVANT FACTOR OFTHREE AREAS ON WTP

\begin{tabular}{|c|c|c|c|c|}
\hline Variables & Chi-square value X2 & Variance & Significance Le vel & Relativity \\
\hline Inhabitation A & 17.659 & 3 & 0.001 & Significant correlated \\
\hline Sex & 0.11 & 1 & 0.915 & Uncorrelated \\
\hline Age & 21.427 & 4 & 0.000 & $\begin{array}{c}\text { Extremely significant } \\
\text { correlated }\end{array}$ \\
\hline Education Degree & 6.584 & 3 & 0.160 & Correlated \\
\hline Occupation & 26.669 & 2 & 0.000 & $\begin{array}{c}\text { Extremely significant } \\
\text { correlated }\end{array}$ \\
\hline Mon thly income & 13.802 & 5 & 0.017 & Significant correlated \\
\hline Ever been to & 5.026 & 1 & 0.105 & Correlated \\
\hline Familiarity & 5.313 & 3 & 0.000 & $\begin{array}{c}\text { Extremely significant } \\
\text { correlated }\end{array}$ \\
\hline Inhabitation B & 149.549 & 3 & 0.000 & $\begin{array}{l}\text { Extremely significant } \\
\text { correlated }\end{array}$ \\
\hline Sex & 1.380 & 1 & 0.240 & Uncorrelated \\
\hline Age & 84.141 & 3 & 0.000 & $\begin{array}{l}\text { Extremely significant } \\
\text { correlated }\end{array}$ \\
\hline Education Degree & 66.958 & 3 & 0.000 & $\begin{array}{l}\text { Extremely significant } \\
\text { correlated }\end{array}$ \\
\hline Occupation & 56.113 & 12 & 0.000 & $\begin{array}{c}\text { Extremely significant } \\
\text { correlated }\end{array}$ \\
\hline Mon thly income & 116.462 & 10 & 0.000 & $\begin{array}{c}\text { Extremely significant } \\
\text { correlated }\end{array}$ \\
\hline Ever been to & 38.563 & 1 & 0.106 & Correlated \\
\hline Familiarity & 53.887 & 3 & 0.000 & $\begin{array}{l}\text { Extremely significant } \\
\text { correlated }\end{array}$ \\
\hline Inhabitation C & 423.586 & 4 & 0.000 & $\begin{array}{l}\text { Extremely significant } \\
\text { correlated }\end{array}$ \\
\hline Sex & 1.993 & 1 & 0.158 & Uncorrelated \\
\hline Age & 116.000 & 4 & 0.000 & $\begin{array}{l}\text { Extremely significant } \\
\text { correlated }\end{array}$ \\
\hline Education Degree & 55.303 & 3 & 0.000 & $\begin{array}{c}\text { Extremely significant } \\
\text { correlated }\end{array}$ \\
\hline Occupation & 60.482 & 12 & 0.000 & $\begin{array}{l}\text { Extremely significant } \\
\text { correlated }\end{array}$ \\
\hline Mon thly income & 183.658 & 8 & 0.000 & $\begin{array}{l}\text { Extremely significant } \\
\text { correlated }\end{array}$ \\
\hline Ever been to & 104.338 & 1 & 0.109 & Correlated \\
\hline Familiarity & 70.255 & 3 & 0.000 & $\begin{array}{c}\text { Extremely significant } \\
\text { correlated }\end{array}$ \\
\hline
\end{tabular}


The investigation data indicates that different questioned people have different paying willingness of the industrial heritage. For those from other places, over $80 \%$ of the questioned people show paying willingness, while those coming from locally, the percentage is approximately $60 \%$. Clearly, those having keen interests in visiting industrial heritages have a higher paying willingness as compare with the local residents. (See Table 6 for details)

\section{B. Test of the Reliability of the Questionnaires}

To investigate the reliability of the investigation results, all the questionnaires investigated were tested by applying the reliability analysis calculation of SPSS17.0 soft ware. It consists of the basic information of all the evaluated items, the simple relativity indexes and relativity indexes amount the remaining indexes with one or two items being removed. (See the details in Table 7)

TABLE VI. PAYING WILLINGNESS OF THE QUESTIONED

\begin{tabular}{|c|c|c|c|}
\hline $\begin{array}{c}\text { Paying willingness } \\
\text { of the questioned }\end{array}$ & $\begin{array}{c}\text { Ang'angxi } \\
\text { district }\end{array}$ & Yimianpo town & $\begin{array}{c}\text { Hengdaohezi } \\
\text { town }\end{array}$ \\
\hline Nonlocal tou rists & $83.2 \%$ & $85.6 \%$ & $81.1 \%$ \\
\hline $\begin{array}{c}\text { Local and } \\
\text { neighboring } \\
\text { inhabitants }\end{array}$ & $60.8 \%$ & $67.4 \%$ & $59.6 \%$ \\
\hline
\end{tabular}

TABLE VIII. RELIABILITY OF THE FACTORS INFLUENCING PA YING W ILLINGNESS

\begin{tabular}{|c|c|c|c|c|}
\hline & $\begin{array}{c}\text { Scale } \\
\text { mean } \\
\text { if Item } \\
\text { deleted }\end{array}$ & $\begin{array}{c}\text { Scale variance if } \\
\text { Item deleted }\end{array}$ & $\begin{array}{c}\text { Corrected Item } \\
\text { total correlation }\end{array}$ & $\begin{array}{c}\text { Cronbach 's Alpha } \\
\text { if Item deleted }\end{array}$ \\
\hline Inhabitation & 46.421 & 66.801 & 0.528 & 0.729 \\
\hline Sex & 46.712 & 65.096 & 0.601 & 0.813 \\
\hline Age & 45.981 & 66.585 & 0.662 & 0.730 \\
\hline Education degree & 46.924 & 64.012 & 0.561 & 0.806 \\
\hline Occupation & 46.823 & 66.009 & 0.519 & 0.808 \\
\hline Mon thly income & 46.142 & 65.048 & 0.635 & 0.833 \\
\hline Familiarity & 46.114 & 65.241 & 0.663 & 0.830 \\
\hline Understanding & 46.098 & 69.734 & 0.559 & 0.716 \\
\hline Ever been the re & 43.783 & 71.265 & 0.229 & \\
\hline
\end{tabular}

TABLE VII. STATISTICS DATA OUTPUTOF RELIABILITY

\begin{tabular}{|c|c|c|c|}
\hline Three areas & $\begin{array}{c}\text { Crowns Bach } \\
\text { alpha } \\
\text { coefficient }\end{array}$ & $\begin{array}{c}\text { Crowns Bach } \\
\text { al pha } \\
\text { coefficient } \\
\text { after } \\
\text { standardizati } \\
\text { on }\end{array}$ & $\begin{array}{c}\text { Scale test items } \\
\text { of } \\
\text { questionnaires }\end{array}$ \\
\hline $\begin{array}{c}\text { Ang'angxi } \\
\text { district }\end{array}$ & 0.732 & 0.766 & 9 \\
\hline $\begin{array}{c}\text { Yimianpo } \\
\text { town }\end{array}$ & 0.827 & 0.831 & 9 \\
\hline $\begin{array}{c}\text { Hengdaohezi } \\
\text { town }\end{array}$ & 0.746 & 0.781 & 9 \\
\hline
\end{tabular}

The figure 9 in the above table represents the number of items of the Reliability analysis, totaling 9 items. By check, the Baja $\alpha$ coeffic ients of the reliability of all the items in the three areas are respectively $0.732,0.827$ and 0.74 , which are all within the range of qualified range. After the standardization, the Baja $\alpha$ are respectively $0.766,0.831$ and 0.781 , all within the qualified range too. This shows that all the investigation items designed this time is reliable with regard to the evaluation of the paying willingness and further research worth conducting to satisfy the analys is demand.

Moreover, it can be seen from the table of the induced reliability of the factors influencing the paying willingness (see Table 8) all the Baja $\alpha$ coefficients for the 9 variables in the questionnaire are $>0.7$, which indicates that all the 9 influencing factors are valid and reliable. Because the coefficients of each ite $m$ and the whole are high and absence of any item brings no big influence on the Baja $\alpha$ coeffic ient, it is thoroughly indicated that all the 9 items can satisfy the statistics demand. 


\section{Composition of the Non-use Value and Its Estimate}

Composition of the non-use value: Viewed from the nonuse value composition of the industrial heritages of the Middle East Railway, as shown in Table 9, in the aspect of existence value estimation, the percentage of the questioned from the area $\mathrm{A}, \mathrm{B}$ and $\mathrm{C}$ who showed the willingness to pay in order to preserve the foresaid industrial heritages and have them continue to last are respectively $46.21 \%, 54.93 \%$ and $29.66 \%$. Concerning the bequest value, the percentages of the questioned having the willingness to pay in order to pass on the heritages to the descendants to use are respectively $31.63 \%, 32.39 \%$ and $48.27 \%$. And in the option value as pect, the percentages of the questioned that are willing to pay to enable the heritages to be used continuously in the future are respectively $22.16 \%, 12.68 \%$ and $22.07 \%$. (See the details in Table 9)

It can be concluded that in the aspect of non-use value composition, percentages of payment motives vary with the areas where the industrial heritages are situated. In principle, the rate of the bequest value is higher than that of the heritage value and the later is higher than that of the option value. While the rate of the heritage value is bigger that its existence value. This looks likely inconsistent with the conclusion, however the further analysis and discussion prove that this is not true. Judged from the actual response from the questioned in Hendaohezi town, where the economy development is far behind that of Angángxi district and Yimianpo town and the questioned are most old people and have low education levels. All these exert influence on the paying willingness in relation to the existence value of the industrial heritages. In contrast, most people residing in Angángxi district and Yimianpo town are in their 26 to 45 years old. They have better education and certain level of payment ability which lead to a comparatively higher spiritual demand, so their payment ability is relatively encouraging. (See Table 9 and 10)

TABLE IX. Percentage OFPayment Motives OF the THREE AREAS

\begin{tabular}{|c|c|c|c|}
\hline Three areas & $\begin{array}{c}\text { Percentage } \\
\text { of the paying } \\
\text { moti ves of } \\
\text { Area A (\%) }\end{array}$ & $\begin{array}{c}\text { Percentage of the } \\
\text { paying motives of } \\
\text { Area B (\%) }\end{array}$ & $\begin{array}{c}\text { Percentage of the } \\
\text { paying moti ves of } \\
\text { Area C (\%) }\end{array}$ \\
\hline $\begin{array}{c}\text { Existence } \\
\text { value }\end{array}$ & 46.21 & 54.93 & 29.66 \\
\hline $\begin{array}{c}\text { Bequest } \\
\text { value }\end{array}$ & 31.63 & 32.39 & 48.27 \\
\hline $\begin{array}{c}\text { Option value } \\
\text { Total }\end{array}$ & 22.16 & 12.68 & 22.07 \\
\hline
\end{tabular}

TABLE X. AGES COMPOSITION AND DISTRIBUTION OF THE THREE AREAS (DRAWN BY THE AUTHOR)

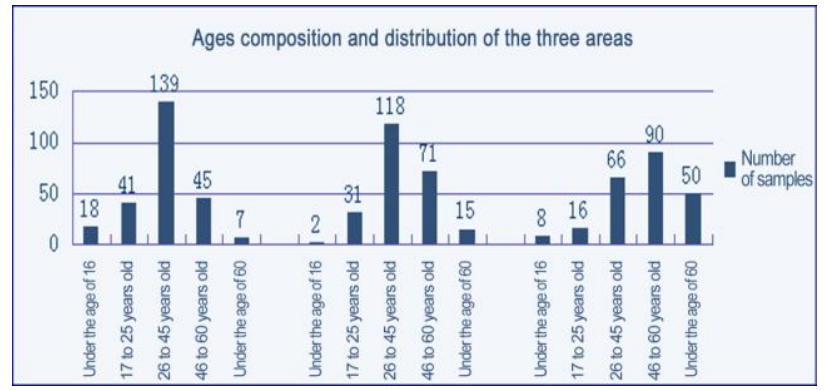

TABLE XI. EDUCATION LEVELS OF THE THREE AREAS (DRAWN BY THE AUTHOR)

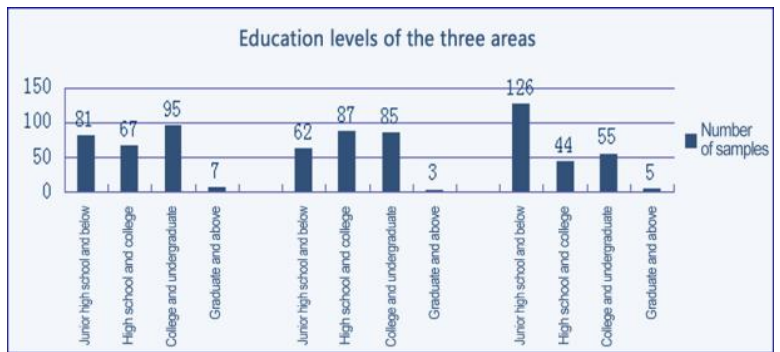

- Estimation of the non-use value of the industrial heritages, As there is a bid difference in WTP calculated by computer, the WTP fails to precisely represent the real paying willingness of the questioned. In this paper, the cumulative median frequency commonly used at the moment is adopted as the WTP estimation value for the non-use value of the industrial heritages of the Middle East Railway. This is because that the median frequency, compared with the arithmetic mean, is free from the influence of the crest value and the least value that are used in the statistics. As it sits in the middle, it is not influenced by the figures change in both sides, thus it processes a better stability and representativeness. So it is fairly reasonable to use the estimation method of median frequency to determine the scale of the nonuse value of the industrial heritages in this research.

- We calculated the bid values of the three areas and acquired the cumulative frequency of WTP from the valid questionnaires and determined the mean paying willingness of the people from these areas by using the cumulative $50 \%$ of the median frequency. The results indicates that the cumulative frequency of Angángxu district nearing 50\% are $45.2 \%$ and $55.9 \%$, with a corresponding paying willingness value being $(35+40) / 2=37.5$ Yuan. That for Yimianpo town are $44.4 \%$ and $45.1 \%,(40+45) / 2=42.5$ Yuan and Hengdaohezi, 50.3\%, 10 Yuan. Therefore we can set respectively the per capita of WTP of the general samples from Angángxi district, Yimianpo town and Hengdaohezi town 37.5 Yuan, 42.5 Yuan and 10 Yuan. 


\section{Validation of the Authenticity of the Research Results}

TABLE XII. The PAYNG WILL INGNESS VAlUE AND THEIR DistRIBUtION OF THE THREe AREAS

\begin{tabular}{|c|c|c|c|c|c|c|}
\hline Three areas & $\begin{array}{c}\text { Payment } \\
\text { incentive } \\
\text { percentage } \\
\text { in region A } \\
(\%)\end{array}$ & $\begin{array}{c}\text { WTP/RMB } \\
\text { in region A }\end{array}$ & $\begin{array}{c}\text { Payment } \\
\text { incentive } \\
\text { percentage } \\
\text { in region B } \\
(\%)\end{array}$ & $\begin{array}{c}\text { WTP/RMB } \\
\text { in region B }\end{array}$ & $\begin{array}{c}\text { Payment } \\
\text { incentive } \\
\text { percentage } \\
\text { in region C } \\
(\%)\end{array}$ & $\begin{array}{c}\text { WTP/RMB } \\
\text { in region C }\end{array}$ \\
\hline $\begin{array}{c}\text { Existence } \\
\text { value }\end{array}$ & 48.31 & 16.80 & 57.81 & 24.50 & 24.32 & 3.0 \\
\hline $\begin{array}{c}\text { Bequest } \\
\text { value }\end{array}$ & 30.40 & 11.50 & 30.56 & 14.70 & 47.15 & 5.2 \\
\hline $\begin{array}{c}\text { Option } \\
\text { value }\end{array}$ & 21.29 & 7.20 & 11.63 & 5.30 & 28.53 & 3.30 \\
\hline Total & 100 & 35.5 & 100 & 44.5 & 100 & 11.5 \\
\hline
\end{tabular}

Owing to the deviation existed with the value estimation method of CVM conditional figure and with the consideration of the influence of various degree on the results exerted by the social characteristics of the areas investigated and the inputting of the questionnaires data, the research team again, after about one year, attracted three groups of sample from the same or similar collectivity to compare the paying willingness by suing the same research and sampling methods from May 10 to May 17, 2014. The results show that all the indexes of the two times investigations are rather close. This indicates that the research results of this time are of high measurable reliability. Therefore, it can be said that the assessment results have high reliability and repeatability. (See the details in Table 12).

\section{CONCLUSION}

The big scale of linear industrial heritages of the Middle East Railway is very rare to see in China. As typical representative of the historical heritages, it is crucially important to carry out protection and evaluation on them. This paper by using quantitative data and conditional value estimation in form of data comparison estimates the non-sue value of the typical areas where the industrial heritages are situated and acquires the related factors influencing the paying willingness. It reflects the currently existing value and significance through the comparison of the per capita payment and the preference of voluntary labor.

The research shows the followings: 1) Some differences exist in the paying willingness of the industrial heritages of the three typical areas: Hendaohezi town has a lower paying willingness value compared with the other two areas. The falling-behind paying willingness can be attributed to the underdevelopment of its economy in this area, generally low level of education, progressive aged-tendency of the local population etc. Moreover, the age, monthly income, occupation, familiarity and residing distance from the heritage and other factors also exert influence on the paying willingness. By the rough calculation of the related materials, at the moment, the number of the large - scale enterprises in Angángxi district; Yimianpo town and Hengdaohezi town are respectively 4, 5 and 2 . The annual income per-capita of the residents from these three places is 8644 Yuan, 11003 Yuan and 5897 Yuan. The percentages of the educated people are respectively $31 \%, 42 \%$ and $19 \%$. These can further show that the WTP value has a normal distribution relation with the economy development, per-head living standards, percentage of people in education. 2) We found during the course of distributing the questionnaires, stronger paying willingness presented in the area where people have a better familiarity with the industrial heritages. In particular, with the deepening of the people's understanding of the industrial heritages and the enhancement of their protection degree, people's paying willingness increases accordingly. Therefore, it is of great importance to strengthen the propaganda regarding the industrial heritages. This would include the promotion thorough newspaper, broadcast, internet, magazine and other Medias. 3) The non-use value of the industrial heritages is also very important in the field of economy.

According to our estimate, the per-head paying willingness of the three areas A, B and C are 37.5/35.5 Yuan, 42.5/44.5 Yuan and 10/11.5 Yuan. Since the industrial heritages of the Middle East Railway involve a big variety of items and numerous people, the economic value it can eventually bring about is potentially huge.4) In view of the fact that in the CVM method, the paying willingness (rather than actual payment) has been concluded through the form of questionnaire, unavoidably some deviation exists between the paying willingness and the actual one. It is our hope that this research can provide reliable reference value to the further research on the industrial heritages of the Middle East Railway. 5) Considering that CVM method has started late in China, and the paying willingness was estimated in forma of questionnaire and ideal money, the paper selected three typical areas to conduct the comparative research, trying to test the reliability and stability regarding the questionnaires and research results. All the research results can meet the demand of the statistics.

In conclusion, through large amount of situ investigation, this paper can provide valid theoretical support and referential grounds for the non-use value of the industrial heritages of the Middle East Railway, even of whole China. Although, great suspect about the accuracy of the CVM method is held by many scholars both at home and abroad, this method clarifies the value composition of the industrial heritages and the future development direction. It is therefore of strong practical significance. 


\section{REFERENCES}

[1] Estimation of the Non-use Value of Shanghai Yuyuan Based on CVM Method by Ni Bin, [J] Chinese Gardens, 201 1(04):63- 64.

[2] Estimation of Non-use Value of Industrial Heritages by Applying CVM Method: Exemplified by the Heritage of Beijing Coke-oven Plant by Tan Chao [J] Journal of Inner Mongolia Normal University (Natural Science Edition), 2009 (03).

[3] Estimation Research System of Non-use Value of Tourism Resources and Cultural Heritages--- Exemplified by Lvshun Taiyang Valley by Zhou Ying, Wang Ertda and Wei Jianhua [J]. Ecological Economy, 2013 (09).

[4] The Research of the Feasibility of Conditional Value Method in the Application of the Green Land in Residential Area by Song Xiuhua, Lang Xiaoxia and Pu Yongji, [J] Chinese Gardens, 2010 (03).

[5] Non-use Value Estimation of the Tourism Resources Using CVMExemplified by the Famous Historical can Cultural City Langzhong by Xu Dongwen, Wang Yingling, Ye Huping and He Meili [J] Journal of Huazhong Normal University (Natural Science Edition). 2008 (04).
[6] The Relevant Study on the Residents' Payment Ability and Paying willingness in the Ecological Function Recovery of Taihu Lake Wet Land based on CVM Method by Yu Wenjin, Xie Jian and Zou Xinqing, Ecology Journal, 201 1(23).

[7] The Current Distribution and Completeness Protection Regarding the Middle East Railway's Industrial Heritages, Tong Yuquan [J]. Urban Development and Research 2013 (04).

[8] Empirical Research of the CVM's Differences in Measurement Indexes and It s Option in the Evaluation of the Resources of Industrial Heritages by Cui Weihua [J] Chinese Population, Resources and Environment, 2013.(9):145-160.

[9] Value Estimation Based on Effectively Improved Recovery Conditions of the Watershed Ecosystem-Exemplified by the Ecosystem Recovery of Yangtze valley by Cai Zhijian, Du Liyong and Jiang Zhan [G], Chinese Population, Resources and Environment, 2011.(1): 125-140. 